\title{
Design and Reflection on Genre Analysis in Junior Middle School English Reading Teaching
}

\author{
Xuehua Zhang* \\ Junior Middle School Department of Nanjing No. 1 Middle School, Nanjing 210000, Jiangsu Province, China \\ *Corresponding author: Xuehua Zhang, 1109289223@qq.com
}

\begin{abstract}
In order to better promote students' English learning ability and interest, this paper expounds the general process of junior middle school English reading teaching by using genre analysis, for the reference of relevant personnel.
\end{abstract}

Keywords: Junior middle school English; English reading teaching; Genre analysis

Publication date: December 2021; Online publication: December 27, 2021

\section{Introduction}

English has become the main language used in various international occasions. Reading is one of the most important language skills for students at all levels of education. The teaching of English reading in junior middle schools is an important part of English education. Improving reading ability is an integral part of the language ability model, which is very important for junior middle school students to improve their reading ability. However, the current teaching still puzzles some teachers and learners. Some people even lose their confidence throughout the process of learning because of the lack of appropriate reading strategies. How then can junior middle school students read more effectively with the limited teaching time?

\section{General goals of English reading in junior middle schools}

Students can input the meaning of new words from the context and word formation rules, understand the logical relationship between each sentence in a paragraph, choose the main ideas in the text, understand the plot in the story, predict its development and possible ending, learn the different and common text types in reading materials, use appropriate reading purposes to find information according to different reading strategies, use dictionaries and other reference materials for learning, as well as read materials other than textbooks, totaling more than 150,000 words. From the perspective of goals, it is necessary for students to help each other, overcome the difficulties encountered in the learning process, and actively explore appropriate learning strategies. This is the soul of the new curriculum standard. In addition, it is extremely important for students to master certain learning skills, which play vital roles in English learning and in many important examinations. Therefore, teachers should introduce common genres to the students at the basic stage of English learning. Only in this way can teachers lay the foundation for students and promote future English learning during high school or even college.

\section{Teaching design of narrative English reading}

Narration is considered the most common style in Chinese and English, even in other languages. The purpose of this design is to allow students to appreciate that narration is usually used to tell a story or describe an event or a series of events. Its categories include story, biography, history, news, articles, and 
poetry. However, the focus of a good narrative is to arrange a story in such a way that it has a beginning, middle section, and an end, no matter what it is used for. Usually, the author will arrange these three parts according to a natural order. However, these sections may be reversed in some cases. The language used in narratives is accurate and vivid. The whole text is organized by clues of times and events. When analyzing a narrative, it is necessary to consider six different components: time, place, character, reason, progress, and the results of the event. By analyzing the six components, students would also be guided by their teachers to analyze the characteristics of narration and to help them better understand the text from the perspective of discourse structure. In junior middle schools, most narrative texts are in the form of stories and biographies; therefore, a typical teaching design has been proposed in the paper, hoping that students would be able to analyze a narrative by tracking the time and clues of events, which would be conducive to gain a clearer understanding of the main ideas of various texts similar to narratives.

\subsection{Textbook selection}

For example, Hollywood's all-time best - Audrey Hepburn.

Audrey Hepburn was one of Hollywood's all-time greatest actresses. She was famous not only in the United States but also in other parts of the world. When Hepburn died in 1993, the world mourned the loss of a great beauty, a great actress, and a great humanitarian.

Audrey Hepburn's life could only be described as "beauty." She did not exchange beauty for anything. Her unshakable perfection came from her focus in the acting profession. Regardless of her aura, Audrey Hepburn was also an ordinary woman with a longing for love and marriage as well as enthusiasm for public welfare.

Audrey Hepburn starred in many classic films, of which her most famous films were Dragon and Phoenix, Breakfast at Tiffany's, Roman Holiday, and My Fair Lady. Every role she played was infused with her own soul, as if it was herself. Audrey Hepburn herself was an icon of the times, even God was willing to kiss her on the cheek. She played a princess in Roman Holiday, so noble and elegant. With playful short hair and a high waist A-line skirt, she led the fashion trend of that era. Until now, such a style is still fashionable.

Hepburn's achievements went beyond the film industry. People remember her not just as a great actress, but also a great humanitarian because she devoted much of her time to charity.

Hepburn had won numerous awards in her life, and these awards could not hide her light. Her friendship with Gregory Peck was also the talk of the town. They appreciated and understood each other. Friendship becomes noble and holy because of transcendence, and it has weight because of holiness and sublimity.

\subsection{Genre analysis}

Based on the ideas of existing papers, the characteristics of the genre of the chosen text should be combined with the analysis of teaching design.

In this passage, the story is arranged according to the six components of a narrative (time, place, role, reason, progress, and results).

Time: 1929-1993

Place: Hollywood

Role: Audrey Hepburn

Reason: Audrey Hepburn's childhood dream was to become a successful dancer, and she actively put her dream into practice. 
Progress: She loved ballet since childhood. She first became a model, and then ventured into the film industry. When playing a role in Monte Carlo Baby, she met Colette, a French writer, and subsequently played the heroine in Gigi. Since then, she moved up the career ladder, participating in the shooting of Roman Holiday, Funny Face, Breakfast at Tiffany's, My Fair Lady, and so on. The film Always was her last appearance on screen.

Results: During her lifetime, she won the Academy Award for Best Actress for her role as a princess in Roman Holiday; she then won the Tony Awards and was nominated for four Academy Awards before she passed away in her sleep in 1993.

By introducing the story in six different components, not only would readers understand the story of Audrey Hepburn, but also have a clear understanding of the genre construction of narrative text. After learning the text, most students would be able to clearly explain that the purpose of narrative text is to introduce people and their experiences. Therefore, in order to master this kind of text, it is imperative to look at the chronological order or the six components of a narrative. Usually, the author will arrange these three parts according to a natural order. However, they may be reversed in some cases. In this paper, the flashback method is used when presenting the story. First, from the sentence, "Audrey Hepburn was one of Hollywood's all-time greatest actresses," the author expounds Audrey Hepburn's greatest achievements by summarizing them in a narrative way. In the next two paragraphs, the author begins to narrate her story, from the beginning to the middle, and to the end of events. Finally, at the last section, it can be appreciated that the author begins to narrate the present information.

From the beginning of the first paragraph, the author directly expounds the results, piquing people's curiosity to learn about the figure who has gained such achievements and what she had gone through, as well as attracting their attention and interest. Therefore, in English reading teaching, teachers should help students establish the necessary schematic structure of narrative types when guiding students to read.

\section{Problems needing attention in guiding teaching with genre analysis}

(1) Discourse structure analysis is a part of teaching activities. In the actual teaching process, it is necessary to take into account the realization of other teaching objectives, such as language knowledge, language skills, emotional aims, and cultural awareness.

(2) The text structure of the same genre is different. For example, in argumentative essays, some may lead to an argumentative thesis by presenting a certain phenomenon, and then answer the topic proposed at the beginning by using different argumentation methods, whereas some directly state the authors' point of view and then demonstrate.

(3) The purpose of genre analysis is not to encourage students to completely turn away from the learning of language knowledge and language skills, but to help them acquire cultural knowledge, understand discourse meaning, and develop thinking quality through listening, speaking, reading, and writing, so as to guide them to explore meanings and solve problems.

\section{Conclusion}

This study found that it is necessary to apply genre analysis to English reading teaching as it helps to train students' communication skills, enhance their awareness of the course, cultivate their ability to apply genre analysis in analyzing different discourses, and improve their reading skill. In this way, students would be inspired, and their confidence as well as reading skill would be enhanced beyond any doubt. 


\section{Disclosure statement}

The author declares that there is no conflict of interest.

\section{References}

[1] Chen X, 2021, Reflection and Analysis on English Reading Teaching in Junior Middle School. Examination Weekly, 2021(22): 97-98.

[2] Li Y, 2021, Discussion on the Strategies of English Reading Teaching in Junior Middle School. North and South Bridge, 2021(6): 175.

[3] Xu Q, 2021, Strategy Discussion on English Reading Teaching in Junior Middle School. Secondary School Curriculum Guidance (Instructional Research), 2021(10): 101.

[4] Zhang J, 2021, Practice and Research on English Reading Teaching in Junior Middle School. Hundreds of Essays, 2021(24): 148.

[5] Xing YM, 2021, Task Design in English Reading Teaching in Junior Middle School. Chinese and Foreign Communication, 28(4): 635-636. 